\title{
Health Related Quality of Life Regarding Physical and Physiological Parameters in Children suffering from Sickle Cell Anemia
}

\author{
Lamiaa Ahmed Elsayed ${ }^{1,3}$, Sahar Mahmoud El-Khedr Abd El-Gawad ${ }^{2,3, *}$ \\ ${ }^{1}$ Pediatric Nursing Department, Faculty of Nursing, Ain shams University, Cairo, Egypt \\ ${ }^{2}$ Pediatric Nursing Department, Faculty of Nursing, Tanta University, Tanta, Egypt \\ ${ }^{3}$ Faculty of Nursing, Umm Al Qura University, Makkah Al- Mukarramah, KSA \\ Email address: \\ sahar.khedr@yahoo.com (S. M. El-Khedr Abd El-Gawad)
}

\section{To cite this article:}

Lamiaa Ahmed Elsayed, Sahar Mahmoud El-Khedr Abd El-Gawad. Health Related Quality of Life Regarding Physical and Physiological Parameters in Children suffering from Sickle Cell Anemia. American Journal of Nursing Science. Vol. 4, No. 2, 2015, pp. 22-30.

doi: 10.11648/j.ajns.20150402.11

\begin{abstract}
Background: Sickle cell disease is an inherited blood disorder characterized by a chronic hemolytic anemia that contributes to painful crises. It is an autosomal recessive disorder caused by production of abnormal hemoglobin $\mathrm{S}$ and is associated with high morbidity and mortality. It may influence the quality of life of children, who may require more frequent hospital care. This study aimed to compare health related quality of life regarding physical and physiological parameters between children suffering from sickle cell Anemia and healthy children. A comparative study that was conducted at Outpatient Clinic and Pediatric Hematological Department in selected hospital at Makkah Al-Mukaramah. A purposive sample composed of 80 children was classified into two groups, 40 healthy children and 40 children suffering from SCD both groups fulfilling certain inclusion and exclusion criteria. Tools: First tool was an observation checklist that was composed of three parts. Second tool was Pediatric Quality of Life Inventory that was used to assess children's quality of life. Results: Most of the children suffering from SCA had low level of QOL physical, social and emotional wellbeing subcategories as compared to healthy children and statistical significant differences were found. There were statistical significant difference regarding weight, arm circumference physical parameters and respiration, systolic blood pressure and oxygen saturation physiological parameter. It was concluded that, sickle cell anemia affect the quality of life of children suffering from it $\&$ There are differences in quality of life between children with sickle cell disease and healthy children. Recommendations: Awareness of parents regarding sickle cell disease helps in improving children's quality of life. Develop an educational program for parents regarding the prevention of sickle cell crises.
\end{abstract}

Keywords: Quality of Life, Children, physical, physiological parameters \& Sickle Cell Anemia

\section{Introduction}

Sickle cell Anemia (SCA) is an inherited blood disorder characterized by a chronic hemolytic anemia that contributes to painful crises and chronic inflammation. SCA leads to oxidative stress, decreased oxygen affinity of sickled hemoglobin, disordered sleep-induced fatigue and cognitive impairment. ${ }^{(1)}$ It is an inherited autosomal recessive condition, this means that genes can be passed on from a parent carrying it to their children. A sickle cell gene must be inherited from both the mother and the father, so that the child has two sickle cell genes. It is usually first presents in the first year of life. ${ }^{(2,3)}$
Sickle cell disease is a common disease present throughout Saudi Arabia, with a high prevalence in the Eastern and Southern regions. The prevalence of SCD in the various regions is reported to be as follows: Qatif (0.170), Gizan (0.103), Makkah (0.025) and Alula (0.081). In Medina, the estimated prevalence of sickle cell homozygosis ( $\mathrm{Hb} \mathrm{SS})$ is 0.01 , and that of the carrier state (Hb AS) is 0.087 . In Khober, a neighboring area, the gene frequency of $\mathrm{Hb} \mathrm{S}$ is 0.239 .2 . $^{(4)}$ Sickle cell disease was detected in 108 of 45.682 children and adolescent. The regional distribution of sickle cell disease showed eastern region dominance with prevalence of 
145 per 10.000 followed by the southern region with a prevalence of 24 per 10.000 , western region 12 per 10.000 and central region 6 per $10.000 .^{(5)}$

Major symptoms of SCA resulting from the abnormally shaped, sickled red blood cells blocking the flow of blood that circulates through the tissues of the body. The tissues with impaired circulation suffer damage from lack of oxygen. This can cause severe disability in children with sickle cell anemia. The patients endure episodes of intermittent "crises" of variable frequency and severity, depending on the degree of organ involvement. The major features of sickle cell anemia include fatigue, anemia, pain crises, eye damage, arthritis and dactylitis. Splenic Sequestration, liver congestion, lung and heart injury, leg ulcers, aseptic and bone infarcts may also occur. ${ }^{(6)}$

Treatment of SCA is directed at the management and prevention of the acute manifestations as well as therapies directed toward blocking the red blood cells from stacking together. There is no single remedy to reverse the anemia, it is important that affected children and their family members have an optimal understanding of the illness. Children and their parents may be adversely influenced when the symptoms can't be managed effectively during pain which may lead to dis-integrity and dis-functionality in the family, loss of energy, increasing care burden, despair and the deterioration of the quality of life (QOL). ${ }^{(7 \& 8)}$

The World Health Organization (WHO) defines QOL as an "individual's perception of their position in life in the context of the culture and value systems in which they live and in relation to their goals, expectations, standards and concerns". It is a broad-ranging concept affected by children's physical health, psychological state, level of independence, social relationships. ${ }^{(9)}$ Quality of life refers to people's ability to function in the ordinary tasks of living. It moves beyond direct manifestations of illness to the patient's personal morbidity. QOL analyses are particularly helpful for investigating the social, emotional and physical effects of treatments and disease processes on children's daily lives; analyzing the effects of disease or treatment from the patient's perspective; and determining the need for social, emotional and physical support during illness. ${ }^{(10)}$

Pediatric health quality of life (HQOL) refers to assessment of the children's physical, emotional, and social well-being. HRQL is a complex patient reported outcome that provides an assessment of how an illness, its treatment, and its complications affect the patient. A good HQOL is important for a child with a chronic condition, such as sickle cell disease, where the likelihood of a cure is little. Moreover, measures to improve HQOL are very important to evaluate prognostic factors, to identify problems that can be targeted by an intervention and aids in understanding of the wellbeing of children with sickle cell disease. Children with SCD have lower baseline HRQL than healthy controls, and worsens during acute vaso-occlusive painful crisis events. ${ }^{(11-13)}$

The goals of nursing care are symptoms control and management of disease complications. Treatment strategies include several goals that include management of vasoocclusive crisis, management of pain syndromes, and hemolytic anemia. They also include, prevention and treatment of infections, management of the complications and the various organ damage syndromes associated with the disease, prevention of stroke, detection and treatment of pulmonary hypertension. ${ }^{(14)}$ The nursing role was directed toward prevention of sickle cell crisis including avoidance situations that increase cellular metabolism; strenuous physical activity, contact sports, emotional stress, high altitudes, infection. Teach children and their mothers about situations that can precipitate a sickle cell crisis and steps needed to prevent or diminish such crises. ${ }^{(15)}$

\subsection{Aim of the Study}

The aim of the current study was to compare health related quality of life regarding physical and physiological parameters between children suffering from Sickle cell anemia and Healthy children.

\subsection{Significance of the Problem}

Sickle cell disease is an autosomal recessive diseases associated with high morbidity and mortality. Caring for a child with sickle cell disease poses extra demands on parents, both physically and psychologically, which may influence children quality of life. The prevalence of SCD in Saudi Arabia varies significantly in different parts of the country, with the highest prevalence is in the Eastern province, followed by the southwestern provinces. Unfortunately, there are few published studies on quality of life related to sickle cell disorder. Most of the studies have reported the impact of the illness on certain domains. ${ }^{(16)}$

\subsection{Research Questions}

- How can sickle cell anemia affect the quality of life of children with SCA?

- To what extent physical and physiological parameters of children suffering from SCA can be affected compared to healthy children?

\section{Subjects and Methods}

A. Research Design: a comparative study design.

B. Research settings: The study was conducted in the Outpatient Clinic and Pediatric Hematological Departments in selected hospital at Makkah Al-Mukaramah.

C. Research Subjects: A purposive sample composed of 80 children classified into two groups. The first group consisted of 40 healthy children. The second group was composed of 40 children suffering from sickle cell disease with their mothers coming to the previously mentioned setting, under the following inclusion and exclusion criteria:

\subsection{Inclusive Criteria}

\subsubsection{For Both Study Groups}

- Children aged from 6-12 years. 
- Free from psychological and communication problems.

\subsubsection{For Healthy Children}

- Free from any chronic disease.

\subsection{Exclusive Criteria for SC Group}

- Children with sickle cell anemia and other disease such as thalassemia.

- Children who had spleenectomy.

D. Tools of Data Collection: Two tools were used for data:

1-First tool: An Interviewing Questionnaire that was developed by the researchers and was composed of two parts:

Part one: socio demographic questionnaire that was used to collect data about mothers and their children. It involved,

A.Mothers' socio demographic characteristics, including their age, gender, years of experience, educational level etc.

B. Children' socio demographic characteristics including, age, gender, school level, history of illness, previous admission to hospital and cause of admission.

Part two: An Observation Checklist that composed of physical and physiological measurements as follow:

A.Anthropometric measurement: it was used to assess physical growth of the children including, weight, height, head circumference, chest circumference and abdominal circumference.

B.Physiological Measurements: it was used to assess Temperature, Pulse, Respiration, Systolic/Diastolic blood pressure and Pulse oximeter.

2-The second tool was Pediatric Quality of Life Inventory (PedsQL):

This tool was adopted from Varni etal (2003). It was used to assess children quality of life. It was composed of 23 items comprising four subscales, the items of the four Scales were: Physical (8 items), Emotional (5 items), Social (5 items), and School (5 items). ${ }^{(15)}$

\subsection{Scoring System}

Pediatric Quality of Life Inventory was consisted of 23 items scored from 1 to 69 . PedsQL was 1-5 Likert scale. In the present study, items were summarized to three likert scale for statistical purpose as follow: 1 never, 2 sometimes and 3 always a problems (with higher scores indicating low QOL).

\begin{tabular}{llll}
\hline Response & Never & Sometimes & Always \\
\hline Raw Scores & 1 & 2 & 3 \\
$1-69$ & $1-34$ & $35-51$ & $52-69$ \\
\hline
\end{tabular}

\subsection{Validity and Reliability}

Before conducting the study the researchers review related literatures using available textbooks, journals, articles, and magazines that help to gather enough information from the both national and international articles. The tools of data collection, QOL scale and Pediatric questionnaire scale were tested for validity by giving the tools to five expertise in the field to review it. Reliability test using Cronbach's alpha was utilized to test the internal consistency of the tools. It was (0.989) for Quality of life scale.

Pilot Study: It was carried out on $10 \%$ of the study subjects to test the clarity, validity and reliability of the study tools. The subjects involved in the pilot study were excluded from the study and the necessary modifications were done.

\subsection{Methods of the study/Administrative Design}

\subsubsection{Ethical Considerations}

Official permission was obtained from the vice dean of research and post graduate studies to conduct the study. The nature and the aim of the study were explained to each member of the participants. The participants are individually interviewed and oral consent was obtained from all mothers and their children. Every effort was made to insure the privacy and confidentiality of the results.

\subsubsection{Field Work}

The actual field work was carried out throughout 4 months from the beginning of August to the end of November 2014. The investigators were available for 4 days/week, in the previously mentioned study settings. The tools were filled by the researchers through individualized interview. The average time needed for completion of the interview was around 15-20 minutes. Socio-demographic characteristics for children and their mothers were obtained initially then; the researchers assessed children both physically and physiologically. QOL questionnaire was fulfilled, to assess children's HRQOL.

\subsubsection{Statistical Analysis and Interpretation of Data}

The collected data were revised, summarized, tabulated and analyzed by using the SPSS Version (15). Descriptive statistics using numbers and percentage, appropriate statistical tests as, simple frequency, mean $\pm \mathrm{SD}, \chi^{2}$ and correlations were used to estimate the statistical significant differences and significant correlations.

\section{Results}

Figure (1) shows distribution of the study sample according to their age. It was clear that, $45 \%$ and $12.5 \%$ of healthy children aged from $6<8$ years and $8<10$ years respectively. Regarding to children suffering from SCA, as seen in the figure, it was observed that $32.5 \%$ and $30 \%$ of them aged from $6<8$ and $8<10$ years respectively. Forty two point five percent and $37.5 \%$ of healthy children and children suffering from SCA respectively aged from $10-12$ years.

Percent distribution of the study sample according to family history of chronic illness was illustrated in Figure (2). It was evident that, $82.5 \%$ of sickle cell children's parents were relatives, compared to $37.5 \%$ of healthy children. Less than one quarter of the SC children's parents (12.5\%) 
perform pre-marital examination compared to $22.5 \%$ of the healthy children. Fifteen percent of healthy children and $25 \%$ of children with SC anemia reported presence of genetic disease in the family. Nearly half of children suffering from SCA (47.5\%) mentioned family history of chronic disease in their families compared to $12.5 \%$ of healthy children.

Table (1) shows percent distribution of the study sample according to their anthropometric measurements. It was observed that, the mean weight of children with SC anemia was $22.38 \pm 5.118$ compared to $25.91 \pm 8.13$ of the healthy children, and there was statistical significant difference between the two groups regarding their weight ( $\mathrm{P}=0.02 *$ ). The mean height of the study group was $125.27 \pm 10.51$ for children suffering from SCA and $126.42 \pm 15$ of the healthy children. Statistical significant difference was found between children with SC anemia and healthy children regarding the mean of arm circumference $17.12 \pm 2.34$ and $19.56+3.94$ for SC children and healthy children respectively ( $\left.\mathrm{P}=0.001^{*}\right)$. The mean of abdominal circumference was $61.7 \pm 5.56$ in SC group while it was $59.27 \pm 8.155$ for a healthy children and there was statistical significant difference ( $\mathrm{P}=0.024^{*}$ ).

As regards in table (2), percent distribution of the study sample according to their physiological measurements revealed that, the mean respiratory rate of children with SC anemia was $21.9 \pm 2.02$ compared to $20.17 \pm 1.39$ of the healthy children and there was statistical significant difference between the study groups regarding respiration ( $\mathrm{P}=0.000^{*}$ ). The mean systolic blood pressure of the study group was $104.9 \pm 9.29$ for children with SC anemia and $100.35 \pm 10.93$ of the healthy children. Oxygen saturation mean, was $96.72 \pm 2.96$ and $99.82 \pm 0.84$ of the SC group and healthy group respectively. There were statistical significant differences regarding systolic blood pressure and oxygen saturation $\left(\mathrm{P}=0.046^{*}\right)$ and $\left(\mathrm{P}=0.000^{*}\right)$ respectively.

Table (3) shows comparison between QOL for children with sickle cell anemia and healthy children regarding to their physical health (subcategories of QOL). It was evident that, most of the SC children $65 \%, 55 \%, 67.5 \%$. were always feel hard to walk, to run, to do sports, compared to $28.2 \%, 44.4 \% \& 25.9 \%$ of healthy children respectively and there were statistical significant differences $(\mathrm{P}=.000 *)$. Nearly equal percent of SC group (72,5\% and 70\% ) always found difficulty to left something heavy, shower by himself, and hard to chores around the house respectively. Physical health of healthy children as revealed in table (3) illustrated that, $30.1 \%, 23.7 \%, 21.9 \%$, and $32.4 \%$ were never feel hard to run, to do sports, to chores around house, and never feel of low energy respectively. There was statistical significant difference between children with sickle cell anemia and healthy children regarding all physical health subcategories.

As regards, comparison between QOL for Children suffering from SCA and healthy children according to their Emotional subcategories of quality of life scale table (4) revealed, statistical significant differences between both study regarding all emotional wellbeing subcategory $(\mathrm{P}=.000 *)$. It was found that $72.5 \%$ of children with sickle cell anemia always feeling afraid or scared compared to $28.5 \%$ of healthy children. Nearly equal percent of the children suffering from SCA reported always response regarding feeling sad (45\%), angry (55\%), trouble sleeping $(55 \%)$ and worry about what will happen to them $(50 \%)$. Never responses regarding emotional wellbeing subcategories were reported by $58.8 \%, 58.2 \%$ $52 \%$ and $49.3 \%$ for feeling sad, angry, trouble in sleeping and worry about what will happen to them respectively.

Regarding to table (5) comparison between QOL for children with sickle cell anemia and healthy children regarding their social wellbeing subcategory. It was clear that, the majority of the children with sickle cell anemia $(92.5 \%, 97.5 \%$, and $92.5 \%)$ were always having trouble getting along with kids, other children didn't want to be their friends and other kids tease them. Never responses were mentioned by $42 \%, 64.3 \%, 59.2 \%$, of healthy children who reported that they never having trouble with kids, other children never refused to be their friends, and other kids never tease them respectively. Sixty percent of the children with sickle cell anemia always can't do things as other kids compared with $33.6 \%$ of healthy children always can't do things as other kids. There were statistical significant differences between children with sickle cell anemia and healthy children regarding all social wellbeing sub items ( $\mathrm{P}$ $=.000 *)$.

Table (6) illustrates comparison between QOL for children with sickle cell anemia and healthy children regarding school wellbeing subcategory of quality of life scale. There are statistical difference between children with sickle cell anemia and healthy children regarding all subcategories of school items $(\mathrm{P}=.000 *)$. It was evident that, $67.5 \%$ of children suffering from SCA were always hardly being attention in class compared with $30.1 \%$ of healthy children. Fifty five percent of the children with SCA were always forgotten things compared with $58.3 \%$ of healthy children who never forgot things. Nearly three quarters of SC group (72.5\% and $77.5 \%)$ were always had trouble keeping up with their school work and always miss school to go to hospital respectively, compared to $69.7 \%$ and $45 \%$ of healthy children who never had trouble keeping up with their school work or miss school to go to hospital respectively.

Table (7) shows Comparison between Total QOL for Children with Sickle Cell Anemia and Healthy Children It was clear that, the majority of the Children with SCA (80\%) had poor QOL regarding physical wellbeing and social wellbeing and $70 \%$ for emotional wellbeing compared to $68.1 \% 58.9 \%$ and $51.5 \%$ of healthy children who reported high physical, social and emotional wellbeing respectively. QOL regarding school wellbeing subcategories revealed that, $60 \%$ of the SC group had low level school wellbeing compared to $21.2 \%$ of healthy children. There were statistical significant differences regarding all subcategories of total quality of life $\left(\mathrm{P}=.000^{*}\right)$. 


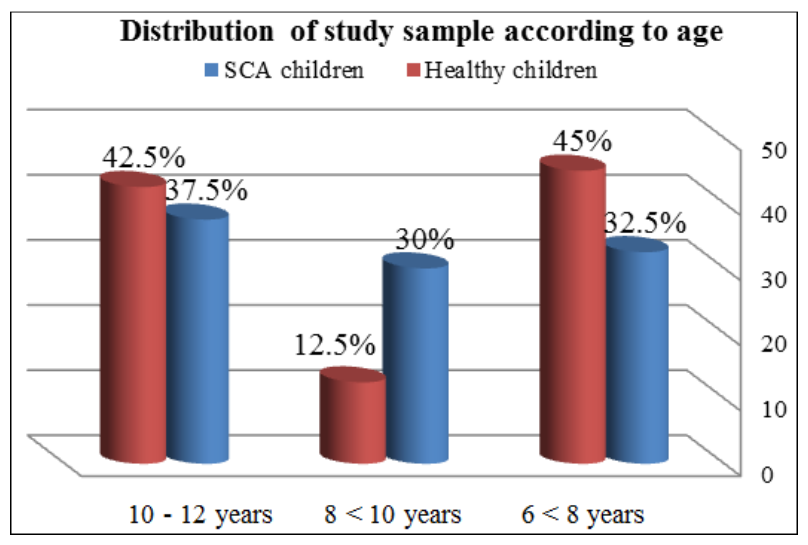

Figure (1). Percent Distribution of the Study Sample According to Age.

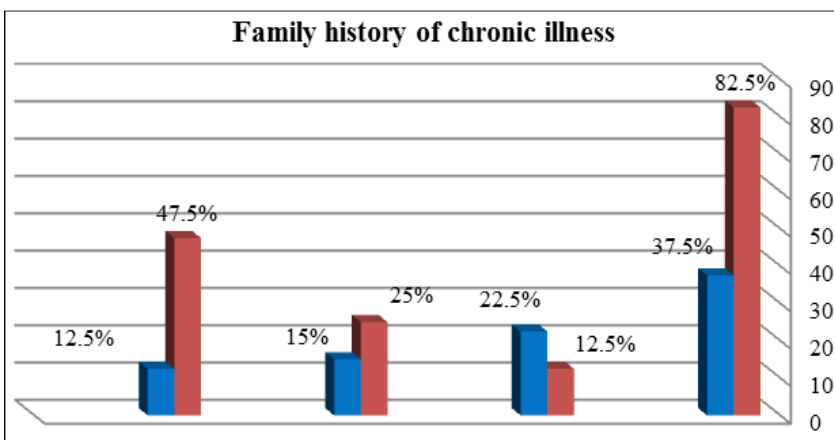

chronic illness Genetic disease Premarital exam. Relationship of parents - SCA Healthy Children

Figure (2). Percent Distribution of the Study Sample According to Family History of Chronic Illness.

Table (1). Percent Distribution of Children with Sickle cell Anemia and Healthy Children According to their Anthropometric Measurements.

\begin{tabular}{|c|c|c|c|c|c|c|}
\hline \multirow{2}{*}{ Anthropometric measurement } & \multicolumn{2}{|c|}{ Sickle Cell Anemia } & \multicolumn{2}{|c|}{ Healthy children } & \multirow{2}{*}{ t- test } & \multirow{2}{*}{ P-value } \\
\hline & Mean & S.D. & Mean & S.D. & & \\
\hline Weight & 22.38 & 5.188 & 25.91 & 8.13 & 2.376 & $.020 *$ \\
\hline Height & 125.27 & 10.51 & 126.42 & 15.16 & .394 & .694 \\
\hline Arm circumference & 17.12 & 2.34 & 19.56 & 3.94 & 3.360 & $.001 *$ \\
\hline Chest circumference & 62.77 & 5.191 & 61.95 & 9.13 & .497 & .621 \\
\hline Abdominal circumference & 61.7 & 5.56 & 59.27 & 8.155 & 1.553 & $.024 *$ \\
\hline
\end{tabular}

Table (2). Percent Distribution of Children with Sickle cell Anemia and Healthy Children According to their Physiological Measurements.

\begin{tabular}{|c|c|c|c|c|c|c|}
\hline \multirow{2}{*}{ Physiological measurements } & \multicolumn{2}{|c|}{ Sickle Cell Anemia } & \multicolumn{2}{|c|}{ Healthy children } & \multirow{2}{*}{ t-test } & \multirow{2}{*}{ P-value } \\
\hline & Mean & S.D. & Mean & S.D. & & \\
\hline Temperature & 36.54 & .44 & 36.53 & .41 & .184 & .855 \\
\hline Pulse & 87.22 & 10.62 & 83.4 & 10.76 & 1.745 & .085 \\
\hline Respiration & 21.9 & 2.02 & 20.17 & 1.39 & 4.567 & $.000^{*}$ \\
\hline Systolic Blood pressure & 104.9 & 9.29 & 100.35 & 10.93 & 2.030 & $.046^{*}$ \\
\hline Diastolic Blood pressure & 67.5 & 12.9 & 69.57 & 11.62 & .695 & .489 \\
\hline Oxygen Saturation & 96.72 & 2.96 & 99.82 & 0.84 & 4. 523 & $.000^{*}$ \\
\hline
\end{tabular}

Table (3). Comparison between QOL for Children with Sickle Cell Anemia and Healthy Children Regarding Physical Health Subcategory.

\begin{tabular}{|c|c|c|c|c|c|c|c|c|}
\hline \multirow{3}{*}{ Physical health Statements } & \multicolumn{3}{|c|}{ SCA children } & \multicolumn{3}{|c|}{ Healthy children } & \multirow{3}{*}{$\chi^{2}$} & \multirow{3}{*}{ p-value } \\
\hline & Always & sometimes & Never & Always & sometimes & Never & & \\
\hline & $\%$ & $\%$ & $\%$ & $\%$ & $\%$ & $\%$ & & \\
\hline It is hard to walk & 65 & 25 & 10 & 28.2 & 27.3 & 42.5 & 160.3 & $.000^{*}$ \\
\hline It is hard for to run & 55 & 27.5 & 17.5 & 44.4 & 25.5 & 30.1 & 38.77 & $.000^{*}$ \\
\hline It is hard to do sports & 67.5 & 12.5 & 20 & 25.9 & 50.4 & 23.7 & 409.6 & $.000^{*}$ \\
\hline It is hard to lift something heavy & 57.5 & 20 & 22 & 24.6 & 20.8 & 54.6 & 38.86 & $.000^{*}$ \\
\hline It is hard to take a shower by myself & 72.5 & 10 & 17.5 & 31.9 & 27.0 & 41.1 & 151.2 & $.000^{*}$ \\
\hline It is hard to do chores around the house & 70 & 12.5 & 17.5 & 41.4 & 36.7 & 21.9 & 87.07 & $.000^{*}$ \\
\hline I hurt or ache & 37.5 & 47.5 & 15 & 39.7 & 24.3 & 36.0 & 105.2 & $.000^{*}$ \\
\hline I have low energy & 27.5 & 47.5 & 25 & 49.0 & 18.6 & 32.4 & 260.7 & $.000^{*}$ \\
\hline
\end{tabular}

Table (4). Comparison between QOL for Children with Sickle Cell Anemia and Healthy Children Regarding their Emotional Wellbeing Subcategory.

\begin{tabular}{|c|c|c|c|c|c|c|c|c|}
\hline \multirow{3}{*}{ Statements } & \multicolumn{3}{|c|}{ SCA children } & \multicolumn{3}{|c|}{ Healthy children } & \multirow{3}{*}{$\chi^{2}$} & \multirow{3}{*}{ p-value } \\
\hline & Always & sometime & Never & Always & sometime & Never & & \\
\hline & $\%$ & $\%$ & $\%$ & $\%$ & $\%$ & $\%$ & & \\
\hline I feel afraid or scared & 72.5 & 20 & 7.5 & 28.5 & 28.5 & 43 & 394.9 & $.000^{*}$ \\
\hline I feel sad & 45 & 40 & 15 & 22.6 & 18.6 & 58.8 & 80.0 & $.000^{*}$ \\
\hline I feel angry & 55 & 35 & 10 & 35.2 & 6.6 & 58.2 & 58.18 & $.000^{*}$ \\
\hline I have trouble sleeping & 55 & 32.5 & 12.5 & 24.9 & 23.1 & 52 & 105.2 & $.000^{*}$ \\
\hline I worry about what will happen to me & 50 & 35 & 15 & 32.1 & 18.6 & 49.3 & 105.2 & $.000^{*}$ \\
\hline
\end{tabular}


Table (5). Comparison between QOL for Children with Sickle Cell Anemia and Healthy Children Regarding their Social Wellbeing Subcategory.

\begin{tabular}{|c|c|c|c|c|c|c|c|c|}
\hline \multirow{3}{*}{ Statements } & \multicolumn{3}{|c|}{ SCA children } & \multicolumn{3}{|c|}{ Healthy children } & \multirow{3}{*}{$\chi^{2}$} & \multirow{3}{*}{ p-value } \\
\hline & Always & sometime & Never & Always & sometime & Never & & \\
\hline & $\%$ & $\%$ & $\%$ & $\%$ & $\%$ & $\%$ & & \\
\hline I have trouble getting along with other kids & 92.5 & 2.5 & 5 & 40.9 & 17.1 & 42 & 79.28 & $.000^{*}$ \\
\hline other kids don't want to be my friend & 97.5 & 0 & 2.5 & 24.2 & 11.5 & 64.3 & 381.7 & $.000^{*}$ \\
\hline Other kids tease me & 92.5 & 2.5 & 5 & 28.5 & 12.3 & 59.2 & 166.2 & $.000^{*}$ \\
\hline I cannot do things that other kids can do & 60 & 22.5 & 17.5 & 54.3 & 9.1 & 36.6 & 96.48 & $.000^{*}$ \\
\hline It is hard to keep up when I play with other kids & 67.5 & 25 & 7.5 & 33.6 & 27.3 & 39.1 & 105.2 & $.000^{*}$ \\
\hline
\end{tabular}

Table (6). Comparison between QOL for Children with Sickle Cell Anemia and Healthy Children regarding their school achievement.

\begin{tabular}{|c|c|c|c|c|c|c|c|c|}
\hline \multirow{3}{*}{ Statements } & \multicolumn{3}{|c|}{ SCA children } & \multicolumn{3}{|c|}{ Healthy children } & \multirow{3}{*}{$\chi^{2}$} & \multirow{3}{*}{ p-value } \\
\hline & Always & sometime & Never & Always & sometime & Never & & \\
\hline & $\%$ & $\%$ & $\%$ & $\%$ & $\%$ & $\%$ & & \\
\hline It is hard to pay attention in class & 67.5 & 25 & 7.5 & 30.1 & 14.4 & 55.5 & 105.2 & $.000 *$ \\
\hline I forget things & 55 & 35 & 10 & 27.6 & 14.1 & 58.3 & 463.2 & $.000 *$ \\
\hline I have trouble keeping up with my schoolwork & 72.5 & 15 & 12.5 & 30.3 & - & 69.7 & 103.7 & $.000 *$ \\
\hline I miss school because of not feeling well & 52.5 & 25 & 22.5 & 22.9 & 35.1 & 42 & 27.40 & $.000 *$ \\
\hline I miss school to go to the doctor or hospital & 77.5 & 10 & 12.5 & 26.1 & 28.9 & 45 & 81.39 & $.000 *$ \\
\hline
\end{tabular}

Table (7). Comparison between Total QOL for Children with Sickle Cell Anemia and Healthy Children.

\begin{tabular}{|c|c|c|c|c|c|c|c|c|}
\hline \multirow{3}{*}{ Items } & \multicolumn{3}{|c|}{ SCA children } & \multicolumn{3}{|c|}{ Healthy children } & \multirow{3}{*}{$\chi^{2}$} & \multirow{3}{*}{ P-value } \\
\hline & Poor QOL & Moderate QOL & High QOL & Poor QOL & Moderate QOL & High QOL & & \\
\hline & $\%$ & $\%$ & $\%$ & $\%$ & $\%$ & $\%$ & & \\
\hline Physical wellbeing & 80 & 12.5 & 7.5 & 20.7 & 11.2 & 68.1 & 748.53 & $.000^{* *}$ \\
\hline Social wellbeing & 80 & 17.5 & 2.5 & 23.3 & 17.8 & 58.9 & 735.72 & $.000^{* *}$ \\
\hline Emotional Wellbeing & 70 & 17.5 & 12.5 & 14.5 & 34 & 51.5 & 121.3 & $.000^{* *}$ \\
\hline School wellbeing & 60 & 17.5 & 22.5 & 21.2 & 29.8 & 49 & 573.72 & $.000^{* *}$ \\
\hline
\end{tabular}

\section{Discussion}

Sickle cell disease is one of the most genetic diseases characterized by the presence of abnormal hemoglobin. In SCA red blood cell become crescents or sickled shaped that hinder blood flow. Sickle red blood cells lead to vasooclussive crises and decreased oxygenations and blood flow to the main organs resulting in severe pain. Sickle cell disease affects millions of people throughout the world, and it is found to be the most common blood disorder among Sub- Saharan Africa, South America, , Central America, Saudi Arabia, India, and the Mediterranean regions. ${ }^{(2)}$ Children have sickle cell anemia need specialized medical and nursing care to obtain good quality of life. Nurses use their potential skills for helping children and their families in the prevention and managements of sickle cell crises to improve the QOL. Therefore, the present study was conducted to compare health related quality of life regarding physical and physiological parameters between children suffering from Sickle cell anemia and Healthy children.

Regarding age of study sample, the present study found that less than half of the healthy children their aged from 6-8 years old compared to nearly one third of children suffering from SCA, It was found that more than half of them SC group aged from 10 -12 years compared to nearly two fifth of the healthy group who aged from $10-12$ years. This findings were in agreement with Manish (2009) ${ }^{(17)}$ who conducted an observational study of children with sickle cell disease in Kilifi, Kenya and reported that, the selected sample was less than 14 years old and the mean age were 6 years. Moreover, the results of the present study is congruent with Ibrahim (2003) ${ }^{(18)}$ who study the cardiac involvement in sickle cell anemia and reported the mean age of SC children involved in his study was 9 years old.

According to family history of chronic illness the current study illustrated that, most of the children with sickle cell their parents were relatives, compared to less two fifth of healthy children. Slightly more than one tenth of the SC children's parents performed pre-marital examination compared to more than two fifth of the healthy children. More than one tenth of healthy children and more than quarter of children with sickle cell anemia were reported presence of genetic disease in their families. Nearly half of children with SCA mentioned family history of chronic disease compared to slightly more than one tenth of healthy children. These results are consistence with the study of Panepinto (2009) ${ }^{(19)}$ who reported that, the parents of children with sickle cell disease were more likely to be African American relatives compared to the parents of children without sickle cell disease. Another study about Growth in children and adolescents with sickle cell disease In Yemen performed by Al-Saqladi (2010) ${ }^{(20)}$ was in agreement with the findings of the current study. They reported high rate of consanguinity that requires improved parental education and pre-marital testing with genetic counseling.

Concerning anthropometric measurements of healthy children and children with sickle cell anemia. The present study found that there were statistical significant differences between both groups regarding the mean weight, arm circumference and abdominal circumference. The current 
study result was congruent with Valavi $(2010)^{(21)}$ who stated that physical growth is affected in children with SCD that are usually lighter. The findings of the current study may be explained by the fact of alteration in children's hematological, cardiovascular status, and endocrine function as well as altered metabolic and nutritional status. Nutrient deficiencies in children with SCD owing to low dietary intake resulting in decreased absorption and increased loss from the gut or increased utilization by the body. Another study conducted by Akohoue (2007) ${ }^{(22)}$ supported the findings of the present study. He reported that, growth monitoring is an important for assessing the health and nutrition of these children as growth status can be a sign of disease activity and severity and its monitoring useful marker of efficacy of medical and/or nutritional interventions.

According to the results of the current study, physiological measurements of children with sickle cell anemia reported that, the mean respiratory rate of children was $21.9+2.02$ compared to $20.17+1.39$ for healthy children and there was statistical significant difference between the study groups regarding respiration. The mean systolic blood pressure of the study group was $104.9+9.29$ for children with SC anemia and $100.35+10.93$ for healthy children. Regarding oxygen saturation it was found that $96.72+2.96$ for children with SC and nearly hundred percent for healthy children respectively. There were statistical significant differences regarding systolic blood pressure and oxygen saturation. These findings may be due to the complication of recurrent SC crises both vasooclusive, and pain crises that affect respiratory rate and $\mathrm{O} 2$ saturation of children suffering from SCA. The results of the current study were consistence with the study of Moreira (2007) (23) who study respiratory repercussions of sickle cell anemia who reported that patients with sickle cell anemia can present an $\mathrm{SpO} 2<90 \%$. Another study by David (2003) ${ }^{(24)}$ supported the current study. He found that children with sickle cell anemia complains of breathless, tachypnea, chest pain, chest signs, reduced oxygen saturations $\cdot$ arterial blood gases / oxygen saturations $<95 \%$, and unexplained drowsiness.

According to comparison between QOL for children with sickle cell anemia and healthy children. It was regarded that, physical health subcategories of quality of life. It was evident that, most of the SC children were always feel hard to walk, to run, to do sports, to left something heavy, shower by himself, and hard to chores around the house respectively. Compared with physical health of healthy children as revealed in the present study were never feel hard to run, to do sports, to chores around house, and never feel of low energy respectively. There was statistical significant difference between children with sickle cell anemia and healthy children regarding all physical health subcategories. These findings were in agreement with Moreira (2007) ${ }^{(23)}$ who study respiratory repercussions of sickle cell anemia \& Asnani (2010) ${ }^{(25)}$ who study the Utility of WHOQOL-BREF in measuring quality of life in sickle cell disease and found that children with sickle cell anemia scored less in physical activity and daily functioning independently.
As regards, comparison between QOL for Children with SCA and Healthy Children according to their Emotional subcategories of quality of life scale. The current study revealed that there were statistical significant differences between the two groups children with sickle cell anemia and healthy children regarding all emotional wellbeing subcategory. It was found that most of children with sickle cell anemia always feeling afraid or scared, less than half percent of children suffering from sickle cell anemia feeling sad. Equal percent of the children suffering from SCA were always feeling angry, always having trouble sleeping and of them were worried about what will happened to them. Compared with healthy children the current study founded that Nearly half percent of healthy children feeling afraid or scared and more than half percent of them were never feeling sad, never feel angry and were never had trouble during sleeping. These results is consistent with kumar (2005) ${ }^{(14)}$ who study psychological effect of chronic illness of sickle cell disease on self-concepts, anxiety level, personnel and social adjustments and found that, sickle cell disease affected daily lives of these children. (14) Another study is in agreement with the results of the present study was conducted by Palermo (2002 ) ${ }^{(26)}$ who reported that, QOL of children with Sickle cell disease are affected by health profile, psychological and functional status of children living with the disease.

Concerning relation between QOL for children with sickle cell anemia and healthy children regarding their social wellbeing subcategory. It was found that, the majority of the children with sickle cell anemia were always having trouble getting along with kids, other friends didn't want to be their friends and other kids tease them. Compared with healthy children more than half of healthy children reported that they never having trouble with kids, other children never refused to be their friends, and other kids never tease them respectively. Moreover more than half of children with sickle cell anemia always can't do things as other kids in the same age group, compared with more than one quarter percent of healthy children who always can't do things as other kids. There were statistical significant differences between children with sickle cell anemia and healthy children regarding all social wellbeing sub items.

These results are incongruent with study of The Center for Children with Special Needs (2012) ${ }^{(27)}$ and Barakat, ( 2008) ${ }^{(28)}$ that reported students feel disenfranchised from classroom activities and classmates, extremes of withdrawal or disruptive behavior are particularly troublesome for school personnel or families. Withdrawal may manifest ina lack of participation in classroom activities or with classmates, daydreaming, a lack of enthusiasm in the process of learning, or opposition to attending school. (22\&24) Another study performed by Archana(2005) ${ }^{(29)}$ are in agreement with the findings of the present study. They reported that children with chronic disease are two point five times more likely to have psychosocial problems in addition to psychosocial disabilities due to their illness and concluded that all domains physical ,psychosocial, cognitive are affected in children with 
sickle cell anemia.

Concerning Quality of life for children with sickle cell anemia and healthy children regarding school wellbeing subcategory of quality of life scale. There are statistical difference between children with sickle cell anemia and healthy children regarding all subcategories of school items. It was evident that, more than half of children suffering from SCA were always hardly being attention in class and always forgotten things compared with more than one quarter of healthy children. Nearly three quarters of children with SCA were always had trouble keeping up with their school work and always miss school to go to hospital respectively, compared more than half and nearly half of healthy children never who had trouble keeping up with their school work and never miss school to go to hospital respectively. These findings were supported by Manish (2009) ${ }^{(17)}$ who stated that excessive absence of children with sickle cell anemia is due to the complications of the disease and sometimes affects children's ability to meet up class work. ${ }^{(18)}$ These results were supported by The study conducted by The Center for Children with Special Needs (2012) ${ }^{(27)}$ who reported that, children with sickle cell disease are frequently absent from school as result of a painful episode, infections or transfusion protocols hospitalization, outpatient visits, and procedures or other illnesses.

Regarding Quality of life School wellbeing for children with sickle cell anemia it was found that always of them were hardly being attention in class children,were always had trouble keeping up with their school work and always miss school to go to hospital compared with more than half of healthy children never miss school to go to hospital. The current results were in agreement with The Center for Children with Special Needs (2012) ${ }^{(27)}$ and Barakat (2008) ${ }^{(28)}$ who stated that frequent absences from school may result in incomplete class work and incomplete development of social skills, disruptive behavior may be displayed through choices or problems in interacting with other children. The findings of the current study may be due to long hospitalizations of children with SCA that, can cause boredom. Also having problems with other children as a result of illness all of these factors may lead to poor QOL.

Regarding Total QOL for Children with Sickle Cell Anemia and Healthy Children. There were statistical significant differences regarding all subcategories of total quality. It was found that, the majority of the Children with SCA had poor QOL regarding physical wellbeing, social wellbeing and emotional wellbeing compared with nearly more than half of healthy children who had high physical, social and emotional wellbeing respectively. Regarding QOL school wellbeing subcategories. The current study revealed that more than half of children with SC anemia had low level school wellbeing compared to less than one quarter of healthy children. . These results are consistent with study of Archana. (2005) ${ }^{(29)}$ who study the quality of life for children with sickle cell anemia and concluded that children who have sickle cell anemia affect on their physical, emotional, social, Quality of life wellbeing. These findings were consistent with
Panepinto ( 2009) ${ }^{(19)}$ who reported that, those children with sickle cell disease have worse HRQL than healthy children who do not have sickle cell disease and concluded that children with sickle cell disease have significantly impaired HRQL, even targeted interventions to improve these children's HRQL are warranted.

\section{Conclusion}

Sickle cell Anemia is a common disease present throughout Saudi Arabia that may affect the quality of life of children suffering from it. The current study found high significant differences between both physical and physiological parameters and HQOL of children suffering from SCA compared to healthy children in the same age. There were differences in quality of life between children with sickle cell disease and healthy children Sickle cell anemia affects physical social, emotional and school wellbeing of children suffering from it.

\section{Recommendations}

The following recommendations are suggested:

- Improving awareness of parents regarding sickle cell disease that help in enhancement children's quality of life.

- Develop an educational program for children and their parents about the prevention of sickle cell crises.

- Further research is needed to study the effect of pain crises on the quality of life of children suffering from SCA.

- Future studies needed with larger samples of sickle cell anemia and on other age groups.

- Improving knowledge, attitudes and practices of sickle cell children's parents about importance of premarital examination and genetic counseling services.

\section{References}

[1] Yawn B.P., George R., Buchanan M.D., etal., Management of Sickle Cell DiseaseSummary of the 2014 Evidence-Based Report by Expert Panel Members JAMA. 2014;312(10):10331048 .

[2] Creary M, Williamson W, \& Kulkarni R.: Sickle Cell Disease: Current Activities, Health Implications, and Future Directions. J. Womens Health (Larchmt) .2007;16:575-82.

[3] Makani J., Williams TN, \& Marsh K. Sickle cell disease in Africa: Burden and Research Priorities. Ann Trop Med Parasitol. (2007); 101:3-14.

[4] Jastaniah W, Epidemiology of Sickle Cell Disease in Saudi Arabia, Annals of Saudi Medicine, 2011 May-Jun; 31 (3):289293.

[5] Mansour M., Mohammed I., Abdullah S., Alherbish A., Ahmed A., \& Al-omar.,The Prevalence of Sickle Cell Disease in Saudi children and adolescent, Saudi Med,. Journal Volume, 2008; 29(10)-1481-1483. 
[6] Julie A., Sylvia T., Cristiane B., Timothy L., Bogdan D., Sandra Sherman-B., Christy B., and James W., Peds QLTM Multidimensional Fatigue Scale in Sickle Cell Disease: Feasibility, Reliability, and Validity., Pediatric Blood Cancer 2014;61:171-177.

[7] Michael RD, Vichinsky E., Behrman RE, Jenson HB, Stanton BF, Hemoglobinopathies In Kliegman, Nelson Textbook of pediatrics. $18^{\text {th }}$ ed. New Delhi: Elsevier Publication;. p. 2026. (2008).

[8] Gustafson S.L.,: Knowledge and Health Beliefs of Sickle Cell Disease and Sickle Cell Trait: the Influence on Acceptance of Genetic Screening for Sickle Cell Trait., Master theses, University of Pittsburgh. (2006).

[9] Xandra W.,1 Janneke Hatzmann, Elske E., Johanna H. Marjolein Peters, Karin F., and Martha G. Quality of Life of Female Caregivers of Children with Sickle Cell Disease: a Survey, Haematological 2008; 93(4):588-593.

[10] Asnani MR, Reid ME., Ali SB, Lipps G, \& Williams-Green P., Quality of life in Patients with Sickle Cell Disease in Jamaica: Rural-Urban Differences, Rural and Remote Health. 2008; 8: 890.: http://www.rrh.org.au.

[11] Claster, S., \& Vichinsky, E. P., Managing Sickle Cell Disease. BMJ, (2003); 327(7424), 1151-1155.

[12] Joshua J, Vichincky E., \& DeBaun M., Overview of the Management and Prognosis of Sickle Cell Disease, Wolters Kluwer, Literature Review Current through: Dec 2014. Available at, http://www.uptodate.com/contents/overview-ofthe-management-and-prognosis-of-sickle-cell-disease.

[13] Hand L. Sickle Cell Treatment Guideline Released. Medscape Medical News. Available at http://www.medscape.com/viewarticle/831603. Accessed September 14, 2014.

[14] Kumar S, Powars D, Allen J, \& Haywood LJ. Anxiety, Selfconcept, Personal and Social Adjustment in Children with Sickle Cell Anemia. J Pediatr, 2005; 88: 859-63.

[15] Varni, J.W., Burwinkle, T. M., Seid, M., \& Skarr, D. The Peds QL, as a Pediatric Population Health Measure: Feasibility, reliability, and validity. Ambulatory Pediatrics, (2003); 3, 329341 .

[16] Jastaniah. W.,: Epidemiology of Sickle Cell Disease in Saudi Arabia, Annals Saudi Medicne, May-Jun 2011; 31(3): 289293.

[17] Manish S., Julie M., Albert N K., Tolu A., Charles R N., Kevin M., and Thomas N W., An Observational Study of Children with Sickle Cell Disease in Kilifi, Kenya, Br,. J., Haematol. Sep 2009; 146(6): 675-682.
[18] Ibrahim ,D Cardiac Involvement in Sickle Cell Anemia in Children ,Master Thesis ,Faculty of Medicine ,Cairo university. (2003).

[19] Panepinto J., A., Pajewski Nicholas M., Foerster Lisa M., Svapna Sabnis, Raymond G. Hoffmann:2009: Impact of Family Income and Sickle Cell Disease on the Health-Related Quality of Life of Children. Qual Life Res (2009) 18:513 .Pages from,9412-8.

[20] Al-Saqladi A.w.., Bin-Gadeen H.A. \& Brabinb, J., Growth In Children And Adolescents With Sickle Cell Disease In Yemen, W. S. Maney \& Son Ltd., Annals of Tropical Paediatrics (2010) 30, 287-298

[21] Valavi E., Ansari M.J. \& zandian K., How to Reach Rapis Diagnosis in Sickle cell disease? Iran J Pediatr, Mar (2010); 20(1):69-74.

[22] Akohoue SA, Shankar S, Milne GL, et al. Energy Expenditure, Inflammation, and Oxidative Stress in Steady-State Adolescents with Sickle Cell Anemia. Pediatric Res 2007; 61:233-8

[23] Moreira G.A., Respiratory Repercussions of Sickle Cell Anemia, J. bras. pneumol. vol.33 no.3 São Paulo May/June 2007, available at http://dx.doi.org/10.1590/S180637132007000300002 .

[24] David R., Guidelines For The Management Of The Acute Painful Crisis In Sickle Cell Disease, British Journal of Haematology, 2003, 120, 744-752.

[25] Asnani M.R., Lipps GE., \& Reid M.E. , Utility of WHOQOLBREF in Measuring Quality of life in sickle Cell Disease, Health Quality of Life Outcomes, 2009,7-75. Available at: http://www.hqlo.com/content/7/1/75

[26] Palermo, T. M., Schwartz, L., Drotar, D., \& McGowan, K. Parental report of Health Related Quality of Life in Children with Sickle Cell Disease, J Behav Med. 2002 Jun;25(3):26983 .

[27] Center for Children withSpecial Needs, Sickle cell disease: Critical Elements of Care, $5^{\text {th. }}$ ed., (2012)., www.cshcn.org.

[28] Barakat, L., Patterson, C., Daniel, L., \& Dampier, C. Quality of life among Adolescents with Sickle Cell Disease: Mediation of Pain by Internalizing Symptoms and Parenting Stress. Health and Quality of Life Outcomes, (2008); 6 (60), p $1-9$.

[29] Archana B., Patel, and Habib G., Quality of life in Children with Sickle Cell Anemia Hemoglobinopathy.,Indian J of Ped.,2005; 72(7) .,567-5. 